\section{Urinary diversion in children}

Sir,

At a time when paediatricians are referring an increasing number of children with spina bifida for urinary diversion, Scott's (1973) admirable article is most helpful. He points out that diversion by ileal conduit does not necessarily prevent dilatation of the upper tract in those who appear to have a normal upper tract at the time of operation, nor does it necessarily prevent further dilatation in those children who already have some dilatation. In other words, the results of surgery 'for incontinence' are not as good as we would wish-even when the surgery is done by an expert in a good unit.

However, before he apologizes too hard for what he has done to a minority of these children, he ought to compare them with a similar group on whom he has not operated. I hope he is doing this now, for while it is interesting to know that a minority of the children acquire dilatation of the upper tracts despite diversion, we would all like to know what would have happened without the operation. Moreover, radiological dilatation is not the only thing that matters in the urinary tract or in the child's life. We need to compare the consequences of both the original state and the diversion, and assess how each affects renal function and, even more importantly, the child's life from the point of view of infections causing illness and incontinence causing misery. Until such a comparison has been reported, diversion procedures by ileal conduit are likely to retain a prominent place in improving the quality of life for many girls with spina bifida.

S. R. MEADOW

Department of Paediatrics and Child Health, The University of Leeds, 27 Blundell Street, Leeds LS1 3ET.

REFERENCE

Scott, J. E. S. (1973). Urinary diversion in children. Archives of Disease in Childhood, 48, 199.

\section{Shunt nephritis}

Sir,

I read with interest the account of a further case of shunt nephritis reported by Dr. Moncrieff and his colleagues (Archives, 1973).

However, Dr. Moncrieff is mistaken when he states that the presence of a high titre of Staphylococcus albus antibody provides 'for the first time, direct evidence of antibody response to this organism'. He reiterates this later in his account. I feel obliged to point out to Dr. Moncrieff that tests for serum antibodies to Staph. albus have been used as a diagnostic tool in this laboratory for over 3 years, and have previously been recommended as a useful adjunct to the diagnosis of colonized Holter shunts and consequent shunt nephritis (Bayston, 1971, 1972).

\section{R. BAYSTON \\ Bacteriology Department, The Children's Hospital, Western Bank, Sheffield S10 2TH.}

\section{REFERENCES}

Bayston, R. (1971). Serological indication of Staphylococcus albus infection in children with colonised shunts. Developmental Medicine and Child Neurology, 13, Suppl. 25, 135.

Bayston, R. (1972). Serological investigations in children with colonized Spitz-Holter valves. Fournal of Clinical Pathology, 25, 718.

Moncrieff, M. W., Glasgow, E. F., Arthur, L. J. H., and Hargreaves, H. M. (1973). Glomerulonephritis associated with Staphylococcus albus in a Spitz Holter valve. Archives of Disease in Childhood, 48, 69.

Dr. Moncrieff replies:

We regret we did not mention specifically the help we received from Mr. Bayston. We were of course aware of the work on antibodies to Staph. albus being carried out in Sheffield, and indeed acknowledged help from the laboratory there. The cases of shunt nephritis mentioned were published after our paper was submitted. Editors. 
TABLE

Serum vitamin $E$ in children with cystic fibrosis

\begin{tabular}{|c|c|c|c|c|}
\hline \multirow{2}{*}{ Ephynal (tablets) } & \multirow{2}{*}{$\begin{array}{c}\text { Vitamin } \mathrm{E} \\
\text { (mg/kg per day) }\end{array}$} & \multirow{2}{*}{$\begin{array}{l}\text { No. of } \\
\text { patients }\end{array}$} & \multicolumn{2}{|c|}{ Vitamin $\mathrm{E}(\mathrm{mg} / 100 \mathrm{ml} \text { serum })^{\star}$} \\
\hline & & & $\begin{array}{c}\text { Pretreatment } \\
\text { (mean and range) }\end{array}$ & $\begin{array}{c}\text { On treatment } \\
\text { (mean and range) }\end{array}$ \\
\hline $\begin{array}{l}2 \times 50 \mathrm{mg} / \mathrm{wk} \\
100 \mathrm{mg} / \mathrm{dy} \\
200 \mathrm{mg} / \mathrm{dy}\end{array}$ & $\begin{array}{l}- \\
>3 \\
>2 \\
>2 \\
>6\end{array}$ & $\begin{array}{r}10 \\
5 \\
7 \\
6 \\
4\end{array}$ & $\begin{array}{l}0.3(0 \cdot 1-0 \cdot 6) \\
0.1(0 \cdot 1-0 \cdot 2) \\
0.2(0 \cdot 1-0 \cdot 3) \\
0.6(0 \cdot 4-1 \cdot 0) \\
0.1(0 \cdot 1-0 \cdot 2)\end{array}$ & $\begin{array}{l}0 \cdot 3(0 \cdot 1-0 \cdot 6) \\
0 \cdot 1(0 \cdot 1) \\
0 \cdot 7(0 \cdot 5-1 \cdot 0) \\
1 \cdot 0(0 \cdot 6-1 \cdot 4) \\
0 \cdot 2(0 \cdot 1-0 \cdot 3)\end{array}$ \\
\hline
\end{tabular}

$\star$ Mean $\pm 1 S D$ in 21 healthy children, $0 \cdot 8 \pm 0 \cdot 2 \mathrm{mg} / 100 \mathrm{ml}$.

We have investigated changes in serum vitamin $\mathrm{E}$ concentration in response to differing doses (Ephynal tablets, Roche) in a group of 18 affected children aged 7 to 12 years (Table) using a modification of the method of Quaife, Scrimshaw, and Lowry (1949). The $2 \times 50$ $\mathrm{mg} /$ week dose was ineffective in all but 1 of the 10 children tested. We therefore increased the dose to 100 $\mathrm{mg} /$ day for all 18 children, and repeated serum estimations after 4 to 8 months. 13 children showed an increased serum vitamin $\mathrm{E}$ concentration, of these $\mathbf{7}$ had had low values before treatment and now had normal levels, and 6 children reached higher levels within the normal range. 5 children failed to respond to this dose; 4 of these patients were given $200 \mathrm{mg} /$ day, but after 2 months or longer their serum levels remained low. The other child who failed to respond to $100 \mathrm{mg}$ /day died in the course of this study. Another child also died, and he had shown a satisfactory increase in serum vitamin $\mathrm{E}$ (pretreatment serum level $0.1 \mathrm{mg} / 100 \mathrm{ml}$, and 0.7 $\mathrm{mg} / 100 \mathrm{ml}$ when treated with $100 \mathrm{mg} /$ day Ephynal). The patients whose serum vitamin $E$ failed to respond to oral therapy did not differ from the rest of the group in terms of height and weight centiles, bowel symptoms, or chest status.

Thus when vitamin $\mathrm{E}$ (100 $\mathrm{mg} /$ day) is given to children with cystic fibrosis, normal serum levels are achieved in most patients. Those not responding to $100 \mathrm{mg} /$ day fail to respond to $200 \mathrm{mg} /$ day.

B. W. TAYLOR, J. L. WATTS, and A. S. FOSBROOKE The Hospital for Sick Children, Great Ormond Street, and Institute of Child Health, Guilford Street, London W.C.1.

We are grateful to Susan Mullen for vitamin E determinations, to Roche Ltd. for financial assistance, and to Dr. A. P. Norman for allowing us to study his patients.

\section{REFERENCES}

Bennett, M. J., and Medwadowski, B. F. (1967). Vitamin A, vitamin $\mathbf{E}$ and lipids in serum of children with cystic fibrosis or congenital heart defects compared with normal children. American fournal of Clinical Nutrition, 20, 415.
Harries, J. T., and Muller, D. P. R. (1971). Absorption of different doses of fat soluble and water miscible preparations of vitamin $\mathrm{E}$ in children with cystic fibrosis. Archives of Disease in Childhood, 46, 341.

Quaife, M. L., Scrimshaw, M. S., and Lowry, O. H. (1949). Micromethod for assay of total tocopherols in blood serum. Fournal of Biological Chemistry, 180, 1229.

\section{Hydroxyproline excretion}

Sir,

In their article 'Hydroxyproline excretion in various forms of growth failure' (Archives, 1973, 48, 127) Teller et al. comment on our comparable study by stating (p. 130), 'Van Gemund et al. (1967) reported a relation between hydroxyproline excretion of normal children and patients with endocrine and non-endocrine growth failure similar to our own findings, though they did not give a hydroxyproline-free diet, nor express their values in terms of $\mathrm{mg}$ hydroxyproline $/ 24 \mathrm{hr}$ per $\mathrm{m}^{2}$.

We think it necessary to inform the interested reader that we explicitly formulated the administration of a gelatine-free diet as well as the expression of our results on normal children as $\mathrm{mg}$ hydroxyproline $/ 24 \mathrm{hr}$ per $\mathrm{m}^{2}$. The Table is taken from our published report.

\section{TABLE}

Urinary hydroxyproline excretion in 34 children aged 3-10 yr

\begin{tabular}{l|c|c|c|c|c}
\hline \multicolumn{1}{c|}{$24 \mathrm{hr}$} & $\mathrm{mg}$ & $\mathrm{mg} / \mathrm{m}^{2}$ & $\mathrm{mg} / \mathrm{cm}$ & $\mathrm{mg} / \mathrm{kg}$ & $\mathrm{mg} / \mathrm{g}$ creatinine \\
\hline Mean & 51.5 & 60.6 & 0.44 & $2 \cdot 29$ & 134 \\
SD & 13.3 & 9.5 & 0.10 & 0.57 & 35 \\
\hline
\end{tabular}

Moreover, we would like to emphasize that, because of the variable urinary excretion ratio of $\mathrm{OHP} /$ creatinine in 